by her daughter, Henrietta Litchfield, two vols., illustrated; The Place-Names of England and Wales, Rev. J. B. Johnston; A History of the Gold Coast and Ashanti, from the Earliest Times to the Beginning of the Twentieth Century, W. W. Claridge, two vols., with map. George Routledge and Sons, Ltd., and Kegan Paul and Co., Ltd.-A Dictionary of Occultism, L. Spence; Giordano Bruno: his Life, Thought, and Martyrdom, W. Boulting; Best Books, part iii. (Classes F-K), W. Swan Sonnenschein. Williams and Norgate.-On the Cosmic Relations: Being an Outline of the Evolution of the Relations between the Soul and the External Universe, and a Summary of the Recognised Relations that are still so immaturely evolved as to be little understood, H. Holt, two vols.

\section{THE BRONZE-AGE INVADERS OF BRITAIN. 1}

SOMEWHERE about the year 2000 B.c., when the peoples of Western Europe were beginning to learn the uses of bronze and to alter the style of their pottery, a race of invaders began to reach our shores who were totally different from any race which had lived in Britain before that time. The ancient British, although of various strains, were all of them of the long-headed type; they had projecting occiputs; their heads appeared as if compressed from side to side. But those Bronze age invaders had rounded heads, with flat occiputs; their heads had the appearance of having been compressed from back to front. European anthropologists name this round-head type of man "Celtic"; they regard him as an offshoot from the racial type which now attains its greatest purity in the mountainous, countries of Central Europe-the "Alpine" type of race. We may take the Bavarian or Savoyard as good modern representatives of the ancient Celtic or Alpine type. They are usually men of short stature, with dark hair and skins, with short and wide faces, regularly modelled features, and rounded heads. The men who invaded England early in the Bronze age and buried their dead in round barrows, were of a different build of body; they were strong, tall, and muscular; they had long faces, rugged features, prominent noses, overhanging eyebrow ridges; we have reason to believe they were fair in hair and complexion. Although these early invaders of Britain had the "Alpine" form of head, it is not among the modern inhabitants of Savoy or of Bavaria that we can hope to find their ancestral stock. We are all agreed that they were continental in origin. Those who have studied our Bronze-age invaders--who have investigated their physical characters, their methods of burial, their domestic animals, their pottery, their weapons and ornaments, are almost unanimously of opinion that we must seek their ancestral home somewhere in that part of Europe which now lies within the bounds of the German Empire. Every year our knowledge of Europe during pre-Roman times becomes more exact, and I propose, once again, in the light of more recent discoveries, and particularly from the point of view of one who is a student of the human body, to seek for the origin of our round-headed ancestry. We shall find that this early invasion of England was but a side eddy of a racial movement which affected almost the whole population of Europe.

How far the British people were exterminated and replaced during the invasions which took place after Roman domination had come to an end is not easily decided. If the Anglo-Saxons brought a new tongue to

1 Presidential Ad'ress delivered to the Royal Anthropologcial Institute NO. 2363 , VOL. 94$]$
England they brought no new physical type; in stature and in head form we cannot distinguish them with certainty from the Britons of the period of Roman occupation, nor from the older pre-Roman population. But in this earlier invasion, which began 2000 years before the Roman legions crossed the Straits of Dover, we have not the same difficulty; so distinctive is the head-form of the Bronze-age or "roundbarrow" men that we recognise the type at a glance; the type was then new to England. Along all the counties on our eastern seaboard, from Caithness in the north to Dorset in the south, we have found the graves of this distinctive round-headed race. The Hon. John Abercromby, who is our leading authority on British pottery, weapons, and ornaments of the Bronze age, is of opinion that the round-headed invaders were few in number, and that, after gaining a foothold in Kent, they gradually spread northwards and westwards throughout our country. With that conception I cannot agree. The south-eastern part of England was apparently only one of the landing places; the researches which were carried out by Canon Greenwell and Mr. Mortimer leave us in no doubt as to their arrival in eastern Yorkshire; the round-heads became masters of it. The counties which bound the Firth of Forth formed another centre of the invasion; the round-heads conquered that part of Scotland. For our present purpose their extensive settlement in the lowlands of Aberdeenshire and along the southern shores of the Moray Firth are the most important. In recent years Prof. Reid and Dr. Alex. Low, of the University of Aberdeen, have made us familiar with the Bronze-age men of the northeast of Scotland. These more northern invaders had their own peculiar kind of round-headedness, a kind remarkably flat on the crown-just as they had their own kind of graves, their own kind of pottery and ornaments. Sixty years ago that pioneer of anthropology-Prof. Anders Retzius, of Stockholm-identified a certain physical type in Aberdeenshire as similar to that which he had seen amongst the peoples in some of the Baltic provinces of Russia. The invaders who settled on the shores of the Firth of Forth, in Yorkshire, and in the south-eastern part of England have, like their more northern allies, their own distinctive traits in form of head, and in fashions of weapons and pottery. We find a difficulty in explaining the distribution and characters of the "roundhead" invasion, if we suppose, as Mr. Abercromby does, that there was only one point of landing, but all our facts find an easy solution if we suppose that the invasion which occurred in the Bronze age, was similar in character and in extent to that which took place in Anglo-Saxon times.

We must presume, then, that those round-headed people, like the Anglo-Saxons, crossed the North Sea; we must presume further that the "round-heads" were then the dominant power in the North Sea. There are certain considerations which make such a presumption difficult to accept. Then, as now, the Continental shores of the North Sea were inhabited chiefly by long-headed peoples. We do know, however, that before the beginning of the Bronze age the "roundheads " had broken through from the hinterlands of Germany and had reached the coast at various points between Scandinavia in the north and Brittany in the south. It is somewhat difficult to believe that a round-headed people were master mariners; seapower has usually been the appanage of long-headed nationalities; the Spaniards, the Portuguese, the Dutch, Norwegians, and British were, and are, predominantly long-headed. However that may be, we know the round-heads reached the Orkneys, the Hebrides, and the western shores. They spread across the lowlands of Scotland and crossed over to 
Ireland, where they formed numerous settlements in the north and east. The late Sir William Wilde believed-sixty years ago-that they were the aboriginal inhabitants of Ireland, but we know now that Ireland had been the scene of many an invasion before the round-heads reached her shores. The invading race spread over the richest parts of England; they reached Wales.

We are not yet in possession of sufficient evidence to determine how far the round-heads replaced the older inhabitants of Britain. There were several parts of England, Wales, Scotland, and Ireland which they failed to penetrate; at least we have not found in these parts their peculiar "round-barrow" graves. But in other parts their influence was pronounced. In the Museum of Comparative Anatomy at Oxford there are seventy skulls of people buried in round barrows during the earlier part of the Bronze age; thirty of them are apparently pure representatives of the round-headed race; among sixty-seven skulls gathered from the older or long barrows there is not a single representative of the round-headed people. Dr. William Wright found that the round-heads formed 29 per cent. of the people buried in the round barrows of Yorkshire. In the Aberdeenshire graves of the Bronze period Prof. Reid observed that eleven out of twelve skulls were of the rounded type. Were we to argue from the people buried in the peculiar graves of the early Bronze period we should infer that the invaders had influenced the British population to a profound degree. We have reason to believe that the people buried in the barrows or in cist-graves represent not the population as a whole but only a class - the richer or governing class. I had occasion recently to examine a hundred skulls from a disused London cemetery -representative of the working population-and found that only three showed clear signs of a Bronze-age ancestry. It is unusual to see a head of this rounded type on a British artisan. It is otherwise in the classes from which we draw our Civil Servants, our squires, and professional men. In a West End club, chiefly recruited from these classes, the Bronze-age type of head can be traced in about 20 per cent, of its members. I have said that the counties round the Firth of Forth were centres of settlement. Sir William Turner found that 25 per cent. of modern skulls from these counties were of the short or rounded type. The population of Kent, which has been the scene of more than one roundlieaded invasion in pre-Roman times, is eminently short-headed, or brachycephalic. ${ }^{2}$

We may speak with equanimity of an invasion which uverwhelmed our country between 3000 and 4000 years ago; it brought in a strain of blood which still exerts its influence on certain classes of our population, and which has given us some of our most eminent men. I will cite only three instances-the first being Charles Darwin-one of the most acute and best balanced intellects ever bred in England. No one who has examined the bust which Woolner modelled from him in life can doubt his Bronze-age ancestry. His resemblance to Tolstoi is more than a superficial one. The second instance I shall cite from Scotland. We know the head-form of King Robert the Bruce, for a cast of his skull was taken before his remains were re-interred in 1819 . An examination of that cast shows that Bruce possessed all the essential features of the Bronze-age race. Lastly, I take an instance from Ireland, where there are many descendants of the Bronze-age invaders, selecting that most lovable of men-Oliver Goldsmith. It is also a matter worthy of note that John Bull, as portrayed

2 See paper on Hythe Crania by Prof. F. G. Parson, Journ. Roy. Anthrop. Instit., rgo8, vol. xxxviii, p. $4 \mathrm{rg}$.

NO. 2363 , VOL. 94$]$ by "Mr. Punch," carries in his form of head a distinct impression of a Bronze-age ancestry.

So far as concerns the basis of the British population the invasion of the round-heads remained without effect; the mass of the people retained the longheadedness which had characterised their ancestors in the Neolithic and later Palæolithic ages. When we turn to France and mark the changes which occurred in her population at a corresponding period, we find the end result was totally different, there was a complete revolution in head-form; from being a longheaded people the majority of the French became round-headed. Long before the end of the Glacial period we find long-headed races in possession in France; even when the Glacial or Pleistocene period had ended and the Neolithic age was well begun, the native tribes of France retained the more ancient type of head. But even in the older or Pleistocene period we find some trace of the short-headed race. The skull found at Chancelade, in the Dordogne, in circumstances which convince us that its owner must have lived in one of the later phases of the Glacial or Pleistocene period, possesses certain definite features in its hinder or occipital region, which show affinity to the round-headed type. In the more superficial strata of a gravel pit at Grenelle, a suburb of Paris, a series of skulls have been found ${ }^{3}$ which show all the features of our invaders of the Bronze age. In deeper and more ancient strata all the skulls were of the long type. There is good reason for believing that the Grenelle skulls, from both the deeper and more superficial strata, are of Pleistocene age.

Apparently then the round-head invasion of France had begun at a much earlier date than in England. M. Salmon collected measurements of the skulls of 688 people who lived in France during the Neolithic period-or, to make my meaning more clear, in a pre-Bronze age-and found that $5^{8}$ per cent. were long-headed, 2 I per cent. round-headed, the rest (2 I per cent.) forming an intermediate group. A late Neolithic sepulchre in the Marne (Petit Morin) yielded a higher percentage of short-heads, viz., 27 per cent., while the long-headed group had become much reduced -34 per cent.

We see then that the round-headed invasion of France took place at a much earlier date than that of Britain. The French invaders, appear to have belonged to a different branch of the round-headed stock. It is true that north of the Seine one frequently sees amongst the skulls of Neolithic France the identical type which invaded Britain; we note the same strong and rugged faces, the same prominent supra-orbital ridges and the same flattened occiputs which characterise our British invaders. We suppose these northern forms must have come, like our ancestors, from across the Rhine. But the majority of the round-heads which then invaded France were of a different type; their foreheads were full and wide and destitute of great brow ridges; their faces were short and wide and of a less massive cast; their occiputs were rounded rather than flattened. They represent exactly what modern anthropologists have in mind when they speak of the "Alpine" race or type. The type deserves that name, for it evidently issued from the western flanks of the Alps and spread gradually over the whole of France. The revolution in headform never passed beyond the Pyrenees. Long before the arrival of Cæsar in Gaul, the majority of the French people had become of the round-headed type. From Cæsar's time onwards the people who lived between the Loire and the Seine have been regarded as the representative of the true Celtic race. Our

3 See "Crania Ethnicı," Quatrefages and Hamy, 1882. 
Celtic-speaking people-the British "Celtic fringe"belongs to a very different European stock.

The anthropological history of Italy is not unlike that of France. Very few remains of the people who lived in Italy before the dawn of the Neolithic period are known, but such as have been found lead us to believe that the early inhabitants were long-headed and apparently members of the dark-haired stock which inhabited the lands surrounding the Mediterranean-members of Prof. Sergi's "Mediterranean Race." Italy, like France, was apparently invaded from the flanks and passes of the Alps. In some of the graves of Lombardy, belonging to a later phase of the Neolithic period, we find skulls of a shortheaded people. Some of these have the massive faces, the great supra-orbital ridges and the peculiar occipital flattening which characterise the Bronze-age invaders of Britain-but others, apparently the more numerous -are of the true Alpine type, the type which has left its influence on France. Long before the Etruscans and Romans had risen into prominence, the roundheads had permeated the northern half of Italy. I have lately examined the collection of crania which Dr. Niccolucci gathered from ancient Etruscan and Roman tombs-they are preserved in the Museum of the Royal College of Surgeons; fully a fifth of them manifest distinct traces of a round-headed ancestry. Collections of modern Italian crania show that the population has become increasingly brachycephalic since Roman times. In that Italy does not stand alone; it has been so with the population of France, Germany, Russia, Austria, and Greece. The anthropological surveys which have been carried out by $\mathrm{Dr}$. Ridolfo Livi on army recruits drawn from all parts of Italy prove that in the southern half of the country the long-headed, dark-haired Mediterranean race is still the dominant population. But northern Italy is eminently round-headed.

It is generally agreed that the ancient Greeks were long-headed, and were members of the Mediterranean race, but apparently before they reached the heyday of their civilisation and of their power, a wave of round-heads had already penetrated the Balkan peninsula and reached the shores of the Mediterranean. The vast majority of the peoples inhabiting the Balkan Peninsula and the Austrian Empire manifest a high degree of brachycephaly. It was not always so along the valley and across the plains of the Danube. For instance, Prof. Toldt, of Vienna, did not find a single round-head in a collection of skulls gathered from ancient graves in upper Austria; 80 per cent. of the modern population is round-headed. So far as we can yet judge, the Danube Valley, in its width and length, was inhabited bv a long-headed population in the Neolithic period. There is, however, an exception - the skull discovered fully thirty years ago by Prof. von Luschan at Nagy-sap, in Hungary, deeply embedded in the loess of the Danube, and presumably pre-Neolithic in date. Apparently before the Neolithic period had ended the round-heads of the true Alpine type began to penetrate the modern bounds of the Austrian Empire. The inrush of German-speaking peoples in post-Roman times did not stay the growing dominancy of the round-heads. Prof. Matiegka, of Prague, found that the remains of people buried in Bohemia during the ninth century A.D. yielded I4 per cent. of brachycephalic skulls, those of the sixteenth century yielded 70 per cent.; modern graves 85 per cent. The diverse peoples of the Austrian Empire-they are really more differentiated in speech than in racial type-have thus become dominated by a round-headed stock in comparatively recent times.

NO. 2363 , voL. 94]
North of the Carpathians the story is the same. On the plains of Russia there are numerous mounds or tumuli-" "kurgans"-containing the remains of ancient Russians. Seventy years ago Russian anthropologists began to investigate these mounds; they found from their contents that some of them dated back to the Neolithic period, others were of the Bronze age. They found, too, that the people buried in the older mounds were of the long-headed typenot unlike the men whose remains lie in our long barrows. The best modern representatives of this type are the inhabitants of Scandinavia--I shall speak of this form as the Scandinavian type. I have examined lately a series of accurate casts-forty in number--made from skulls found in these ancient Russian mounds. Twenty-seven of these are of the Scandinavian tvpe; only eight of them are roundheaded. Of these eight, five show the features of our invaders of the Bronze age-the massive face, the strongly marked supra-orbital ridges, the flattened occiput. The remaining three are more of the Alpine type. The vast majority of the people within the bounds of European Russia are now brachycephalic; only in those Baltic provinces which lie to the south of the Gulf of Finland has the ancient Scandinavian type succeeded in surviving. In Finland, itself, the Scandinavian type has been replaced by the modern brachycephalic Finn. So far as we have gone the western parts of Russia afford the most probable cradle for the British invaders of the Bronze period.

The anthropological history of Germany is very similar to that of western Russia. To the eye of the anthropologist the modern German Empire falls into three very distinct, but very unequal parts. There is, in the first place, the western or coastal area-embracing Oldenburg, Holstein, Hanover, and parts of Westphalia, where the Scandinavian or Anglo-Saxon form of head is still the dominant type. From the evidence afforded by ancient graves, we have no doubt that the coastal or western German does represent the Neolithic population of Germany, and he does not differ materially from the ancient long-headed native of western Russia. Then there is the second or southern area, including Bavaria, Wurtemberg, Baden, and the upper areas of the Rhine Valley. The modern population of these lands is eminently brachycephalic. Anthropologists are agreed in regarding them as typical representatives of the Alpine race. When and how the change in head-form was effected in South Germany we do not know definitely, but ancient graves, even down to the time of the disruption of the Roman Empire, yield skulls of the long or Scandinavian type. Bavaria, Wurtemberg, and Baden have undergone a revolution in head-form, not unlike that which has overtaken the Austrian Empire and France. In all of them the primitive population has become "Alpinised." In the remaining part of the German Empire-the part which may be described as Prussian, and which contains at least two-thirds of the total population of the Empire-a transformation in head-form has occurred, very similar to that which has overtaken the earlier inhabitants of Russia. German anthropologists have made no attempt to estimate the extent to which the modern Prussian population has assumed the Russian or Slav form of head, nor has any special endeavour been made to ascertain when the change took place. Prof. Welcker of Halle, found that out of a small collection of thirty German skulls eighteen were brachycephalic. In an ancient Prussian cemetery which had been used between the ninth and twelfth centuries, 30 per cent. of the skulls were of the long type and 18 per cent. of the round. Four centuries ago Vesalius regarded flatten- 
ing of the occiput-such as frequently occurs in our Bronze-age invaders - as a characteristic feature of the German head.

We look in vain for the ancestors of our Bronzeage invaders among the modern peoples who live along the German or Dutch shores of the North Sea. When, however, we turn to the investigations carried out by Danish anthropolgists during the last seventyfive years we find a key to our problem. The classical researches of Nilsson brought to light in the Neolithic graves of Denmark a people with exactly the same rounded form of head as that of our British invaders. It was at first believed that these round-heads were the original inhabitants of Denmark, but later discoveries showed that the long-headed race of the long-barrow or Scandinavian type-which also occurred in Neolithic graves-was the older form. Our Bronze-age ancestors had reached the Danish peninsula in the Neolithic period. Recently Prof. Nielsen has published a very instructive table, showing how the headform has altered at various periods in Denmark. His table is as follows:-

\begin{tabular}{lccccccc} 
& \multicolumn{2}{c}{$\begin{array}{c}\text { Dolicho- } \\
\text { cephalic }\end{array}$} & \multicolumn{2}{c}{$\begin{array}{c}\text { Mesis- } \\
\text { c.-phalic }\end{array}$} & \multicolumn{2}{c}{$\begin{array}{c}\text { Prachy- } \\
\text { cepalic }\end{array}$} \\
Neolithic period & $\ldots$ & 50 & $\ldots$ & 44 & $\ldots$ & 26 \\
Early Iron pericd & $\ldots$ & 60 & $\ldots$ & 29 & $\ldots$ & 3 \\
Modern & $\ldots$ & $\ldots$ & I2 & $\ldots$ & 55 & $\ldots$ & 33
\end{tabular}

The table shows that after the Neolithic invasion round-heads became almost as common as long-heads in Denmark. It will bc remembered that the roundbarrows have revealed a similar proportion in England. A further parallel between Denmark and England is seen in the fate of the round-heads. By preRoman times the long-head had again asserted its dominance in both countries; in Denmark the roundheads form only 3 per cent. of the pre-Roman grave sliulls. But after the Roman period the histories of the two countries diverge; the high proportion of long-heads disappeared from the Danish population, so that now they form only about 12 per cent. There can be little doubt as to the cause of the recrudescence of round-heads in Denmark. Her land-frontier is open to Germany and her population has undergone a change in head-form similar to that which has overtaken the people of Prussian Germany in post-Roman times.

In Denmark, then, we may recognise two invading waves of round-heads; but it is the oldest--the Neolithic wave-containing men marked by all the physical characters which we recognise in the English round-barrow men which interests us here. That was the first wave of round-heads to break through the long-headed population in Western Europe and reach the shores of the North Sea. Before the next wave broke, the Danes had apparently become again a long-headed people. Denmark was not the only country to suffer from the first invasion. Our "roundbarrow" race had formed the settlements in the south of Sweden ard on the south-western coasts of Norway. Even now, as in parts of England, the descendants of that early invasion can be traced in the lands in which the round-heads settled. The round-heads also reached the lands at the mouths of the Elbe, Wesser, and Ems. Oldenburg, between the estuaries of the Wesser and the Ems, has yielded Neolithic graves. Out oi four skulls from such graves one is similar in form to that of our Bronze-age invaders. Apparently, too, they reached the coast by ,way of the Rhine. At least the Dutch people living in districts near the mouth of the Rhine show a much higher degree of brachycephaly than their neighbours either to the north or south. We have already traced the entrance of our Brcnze-age type into northern NO. 2363 , VOL. 94$]$
France in the Neolithic period. They, too, reached the coast of Normandy.

We have made a tour round Europe in search of the native land of our Bronze-age invaders. We have merely found secondary settlements along the eastern shores of the North Sea and the possible points of their embarkation. Their native land we have not discovered. Our predecessors, when in difficulty over the origin of a European race, fell back on Asia; they had an infallible belief in the racial potentiality of that continent. There is now a distinct change amongst European anthropologists in their attitude towards such problems. They believe that our own continent may have produced its own races. But so far we have searched in vain for the cradle of the European round-headed stock; we have found neither the beginning of the dark-haired true Alpine type nor of the fair-haired northern form from which our round-barrow men sprang. But it is lawful for us to infer that the centre of dispersion is the probable cradle of origin. Now all the evidence at our disposal points to the central mountainous region of Europe as the centre of dispersion. It is therefore in the plains along the northern flanks of the central mountainous region of Europe that we may expect to find the cradle of our round-headed British ancestry.

The conquest of Europe by the "round-heads" is one of the most amazing revelations of prehistoric research. The outlook for the future of the fairhaired, long-headed stock does not, at first sight, seem very promising. Prof. Gustav Retzius, when he delivered the Huxley Lecture before this institute in Igog, gave expression to such a view. "There lie," he said, "in the circumstances to which I have called attention, a very real danger of the north European long-headed race not being able to hold its own. Just as it has been ousted during the past thousand years from Germany and other countries in Central and Eastern Europe by the dark-haired, small-statured round-heads, it will probably have to yield in Britain too, and be reduced in numbers, perhaps by degrees disappear entirely out of the fatherland of their ancestors and of themselves, by reason of the everincreasing might and power of industrialism with which they seem ill-fitted to cope successfully in the long run. The prospect is depressing, it cannot be denied, but the development of things in the world is not seldom harsh and unmerciful."

Prof. Retzius's statement is that of a man who commands the respect and esteem of all anthropologists; he speaks of the fate of his own-the Scandinavian-racial stock, and is therefore predisposed to take the most hopeful outlook possible. It is beyond denial that in France, Austria, Russia, and in the greater parts of Germany and Italy a round headed stock has ousted a long-headed one. Scandinavia, England, and Spain have escaped this domination by reasori of their comparative isolation. Yet I dare think the future of the big-bodied, fairhaired, long-headed Eurr pean stock may be more prosperous than Prof. Retzius is inclined to think. In the first place we have clear proof that at one time-some 4000 or 5000 years ago-the round-headed stock did break through and reach the western shores of Europe. It leavened England, but became submerged; it met a similar fate in western Germany and in Holland. In the earlier centuries of the present era the long-heads in north-western Europe must have undergone a recrudescence in numbers and in power. They broke eastwards on the plains of the Vistula and Danube; they imposed their speech on the conquered peoples, but the vanqu: shed imposed on them their features of face, head, and body. They broke westwards into France, and lost both their 
tongue and their head-form; they crossed the North Sea and kept both their tongue and their shape of head. Sea power is also a potent factor in anthropology, and so far such power in Europe has been in the hands of long-headed stocks. What the longhead has lost in Europe he has gained in countries which lie beyond the seas, by virtue of his command of the sea. It is too soon to speculate on what the head-form of these new trans-oceanic settlements is to be-but all the signs point rather to a victory of the long-heads.

\section{UNIVERSITY AND EDUCATIONAL INTELLIGENCE.}

LONDON.-The following advanced courses of lectures, to which admission is free, are now being delivered:-A course, with practical work, in dynamical meteorology, at the Meteorological Office, South Kensington, S.W., by Dr. WV. N. Shaw; a course on the Protozoa, at the Lister Institute of Preventive Medicine, Chelsea, S.W., by Prof. E. A. Minchin; a course on metabolism in infancy, at Guy's Hospital, Borough, S.E., by Dr. M. S. Pembrey and Mr. J. H. Ryffel; a course on certain aspects of British ecology, at University College, Gower Street, W.C. The remaining lectures of the last-named course are by Prof. R. H. Yapp (fen vegetation), Prof. G. S. West (the occurrence and distribution of fresh-water algæ), and Mr. A. D. Cotton (the algal vegetation of the salt-marsh and seashore).

Manchester.-The Council of the University, with the approval of the Board of Agriculture and Fisheries, has appointed Mr. W. Percy Middleton Stock Officer for the counties of Lancashire and Cheshire. Mr. Middleton will be attached to the Department of Agriculture, and will be given an office in the University buildings as well as an office in a central position in each of the two counties.

OxFORD.-The annual report of the Committee for Geography, just published, gives a full account of the work done in the geographical department during the past year. The number of students working at geography was forty-one (twenty-three men and eighteen women). Lectures to the number of I24 were delivered by the professor (Dr. A. J. Herbertson, Wadham College) and his assistants, the subjects including natural regions of the British Empire, economic geography, Central Europe, the geographical distribution of man, climate and vegetation regions, topography of Europe, the Oceans, the British Isles, meteorology, influence of the geography of Greece on its political history, and the art of geographical description. Besides these, special lectures were given by Prof. T. Edgeworth David, Sir Ernest Shackleton, and others. Many field excursions were undertaken, and the report includes a long list of gifts to the library and collections. A successful vacation course was held in August, which was attended by 160 pupils ( 54 men and ro6 women).

ShefField.-Dr. A. J. Hall has been appointed to the post of lecturer in medicine.

The Central Committee for National Patriotic Organisations, 62 Charing Cross, W.C., has issued, at the price of $2 d$., a list of publications bearing on the war. It comprises the titles of works likely to be useful to those persons anxious to understand the immediate causes and remote origins of the war, of volumes dealing with the war itself or with naval and NO. 2363 , VOL. 94] military matters generally, and of pamphlets on these subjects sold at $6 d$. or less. Full particulars are given as to where the volumes may be procured, and the pamphlets may be purchased through the Central Committee.

IT was announced to the students of Stevens Institute of Technology at their annual dinner in the Hotel Astor on January 23 that their ten-day campaign to raise $272,000 l$. had yielded $232,8_{54} l$. , and that an extension of time had been granted in which the remainder might be collected. Science says that Dr. A. C. Humphreys, president of the institute, made the confident prediction that the whole amount would be raised by the end of the week. From the same source we learn that the Harvard University corporation has set aside $20,000 l$. to pay Belgian professors who have been driven from their land by the war and may give courses at Harvard University next year. Mr. J. R. Magee has left $4000 l$. and a certain further residuary portion of his estate to Haverford College, to be added to the general endowment fund.

THE Association of Teachers of Domestic Subjects has issued its annual report for IgI4. During the year important work was accomplished by the association. Miss Ailsa Yoxall's book on the "History of the Teaching of Domestic Economy" was completed for the association; it was reviewed in the issue of NATURE for November ig last (vol. xciv., p. 308). A long-considered salary scale received its final form, and suggested a rate of pay which, if adopted by education authorities, would bring domestic subjects teachers into line financially with those of general subjects. We understand the suggested scale is receiving sympathetic consideration by various education authorities. The report contains detailed accounts of the activities of the different branches of the association throughout the country, and these provide satisfactory evidence of a widespread desire to improve the teaching of the important practical subjects with which the members are particularly concerned.

\section{SOCIETIES AND ACADEMIES. LONDON.}

Royal Society, February 4.-Sir William Crookes, president, in the chair.-Prof. G. H. Bryan and $R$. Jones : Discontinuous fluid motion past a bent plane, with special reference to aeroplane problems. The present investigation is based on the theory of discontinuous fluid motion, and in particular on the recent developments of that subject by Sir G. Greenhill. Its object is to obtain a hydrodynamical estimate of the effects of camber on the lift and drift of a lamina moving through a fluid, the motion being two-dimensional, and regarding' the lamina as an aerofoil. Instead of considering continuously curved laminæ, the investigation deals with laminæ the front and rear portions of which are plane, but which meet at a dihedral angle. The method is applicable to surfaces with two or more bends. The general conclusions are in agreement with experimental results, that a moderate degree of camber is beneficial in increasing the lift without a corresponding increase in drift.-Prof. A. Fowler: A new type of series in the band spectrum associated with helium. The band spectrum associated with helium, as previously described by Curtis and Goldstein, includes bands with single heads and bands with double heads. A preliminary analysis of this spectrum has led to the following conclusions:-(I) The doublets do not follow the ordinary law of band spectra, but can be arranged in two series of the type hitherto exclusively 